\title{
THE EFFECT OF LEADERSHIP, ORGANIZATIONAL CULTURE AND COMPETENCY ON EMPLOYEE PERFORMANCE WITH WORKING DISCIPLINES AS INTERVENING VARIABLES IN THE KSOP OFFICE FOR SPECIAL BATAM
}

\author{
Abdurr Rohmat ${ }^{1}$, Bambang Satriawan ${ }^{2}$, Indrayani ${ }^{3}$, Muamar Khadafi ${ }^{4}$ \\ ${ }^{1,2,3}$ Faculty of Economics, Department of Management, University of Batam \\ ${ }^{4}$ Fakultas Ekonomi, Universitas Malikussaleh Lhokseumawe \\ E-mail: ${ }^{1)}$ abdurrohmat26@ gmail.com
}

\begin{abstract}
The purpose of this study was to analyze the influence of leadership, organizational culture and competence on employee performance with work discipline as an intervening variable at the Batam Special KSOP Office. The study population consisted of 122 Civil Servants and 36 Honorary Batam Special KSOP Office. The sample selection method used was simple random sampling, which is a random sampling of the population based on the probability frequency of all members of the population. The spread of the questionnaire was carried out on 36honorary employees of the Batam Special KSOP Office. The data analysis technique used to solve the problem in this research is quantitative analysis technique, namely path analysis with the application of multiple linear regression models using the help of the SPSS 24.0 program. The results of this study indicate that Leadership and Competence have a significant positive effect on Work Discipline. Organizational Culture has a positive but not significant effect on Work Discipline. Furthermore, leadership has a positive and significant effect on employee performance. Organizational Culture has a positive and insignificant effect on Employee Performance. Competence has a negative and insignificant effect on employee performance. As for the work discipline variable, it has a positive but insignificant effect on employee performance.
\end{abstract}

Keywords : Leadership, Organizational Culture, Competence, Work Discipline and Employee Performance

\section{INTRODUCTION}

Humans are one of the resources that can determine the success of an organization in carrying out its institutional activities. Human resources are an important asset and play a role as the main driving force in the implementation of all agency activities. And human resources in an institution are a group of people who work in an organization and they have different initiatives, ideals and races. Human resources are still the main focus and foundation for organizations to survive in the era of globalization. The achievement of goals is influenced by the performance of the organization's employees themselves. Failure to meet needs, wants and expectations, as well as an unfavorable work environment can weaken employee motivation which results in weak employee performance.

Quality human resources are seen from the performance of an employee in carrying out their duties, in accordance with what has been assigned to them. An important factor that determines employee performance is the organization's ability to adapt to environmental changes. Employee performance is needed because with performance it is known how far the employee's ability to carry out the tasks assigned to him. Employee performance in this case is the Batam 


\section{THE EFFECT OF LEADERSHIP, ORGANIZATIONAL CULTURE AND COMPETENCY ON EMPLOYEE PERFORMANCE WITH WORKING DISCIPLINES AS INTERVENING VARIABLES IN THE KSOP OFFICE FOR SPECIAL BATAM}

DOI: https://doi.org/10.54443/ijset.v1i2.8

Special KSOP employee can be seen from the employee's ability to carry out and complete the tasks and services that are their responsibility.

Batam Port Authority and Harbormaster Office (KSOP) Class III is a Technical Implementation unit (UPT) within the Directorate General of Sea Transportation which is located and is responsible to the Director General of Sea Transportation, has the task of carrying out supervision and law enforcement in the field of shipping safety and security, coordination government activities at ports as well as regulating, controlling and supervising port activities at ports that are commercially operated. Problems related to human resources in an organization demand attention, because no matter how sophisticated the technology is used in an organization and no matter how big the organization's capital is, the employees in the organization who ultimately run it. This shows that without the support of good quality employees in carrying out their duties, organizational success cannot be achieved. The contribution of employees to an organization will determine the progress or decline of the organization. The contribution of employees to the organization will be important. If done with effective action and behave correctly. The characteristics that exist in employees, the effort or willingness to work and various things that are the support of the organization are of great significance for the success of employee performance. Thus, employees need to know exactly what their main responsibilities are. What kind of performance must be achieved and can measure itself according to the indicators of success.

One of the factors that can make human resources into a resource that has good performance is the leadership, if the leader directs, guides and helps employees in solving the problems faced, employee performance can also be improved. Leadership as a process of influencing other people to act in order to achieve predetermined goals. A leader must be able to transform the organization to meet new realities, the leader plays an important role in ensuring that organizational members know, understand and accept the core values of the organization that are relevant in making decisions as a step in achieving organizational goals.

The second factor that may affect employee performance is Organizational Culture. Organizational culture is a system of beliefs and values that develop in the organization and direct the behavior of its members. In business, these systems are often thought of as a corporate culture. No two persons are the same, no organizational culture is identical. Experts and consultants believe that cultural differences have a major influence on organizational performance and the quality of work life experienced by organizational members (Schemerhorn, 1994) in Raisa (2009: 10).

In addition to leadership and organizational culture, competence can also affect employee performance (Makawi et al, 2015). Competence is an aspect of a person's ability which includes knowledge, skills, attitudes, values, or personal characteristics that enable workers to achieve success in completing their work through the achievement of results or success in completing tasks (Noe, 2002: 94). Furthermore, the behavior that shows the condition of employee competence does not meet company expectations, for example: not fast enough in solving problems, not innovating at work because they are always waiting for orders from superiors, there are still many complaints from customers about the lack of readiness of employees in the field, not understanding good work standards, Based on the background and description above, the authors are interested in conducting research with the title "The Influence of Leadership, Organizational Culture and Competence on Employee Performance with Work Discipline as an Intervening Variable at the Batam Special Ksop Office". 
Figure 1.1

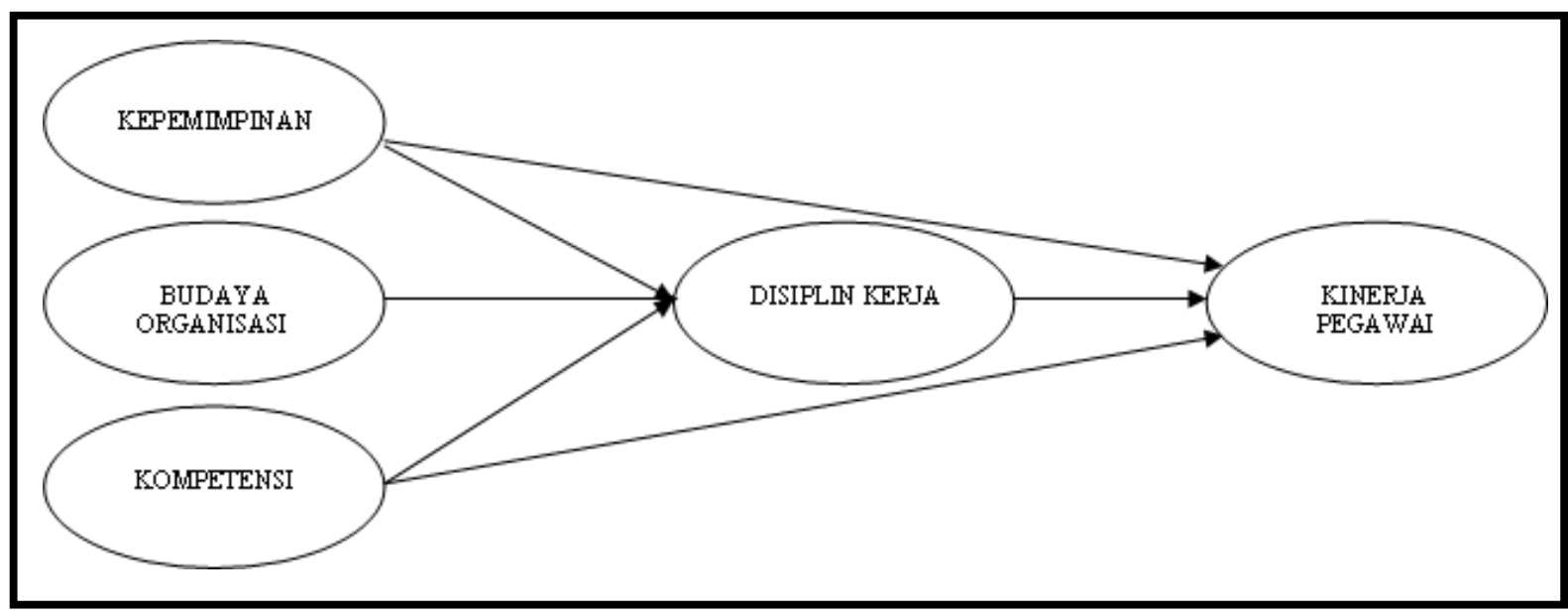

Research Model

\section{IMPLEMENTATION METHOD}

This study uses a quantitative approach by examining the facts that have occurred and all data and information in the form of numbers, with parametric statistical analysis. This research is a type of quantitative research that aims to provide empirical evidence of the influence of leadership, organizational culture and competence on employee performance with work discipline as an intervening variable at the Batam Special KSOP Office.

The study population consisted of 122 Civil Servants and 36 Honorary Batam Special KSOP Office. The sample selection method used was simple random sampling, which is a random sampling of the population based on the probability frequency of all members of the population. The spread of the questionnaire was carried out on 36honorary employees of the Batam Special KSOP Office. The data analysis technique used to solve the problem in this study is quantitative analysis technique, namely path analysis with the application of multiple linear regression models using the help of the SPSS 24.0 program.

\section{RESULTS AND DISCUSSION}

Based on the results of data analysis using the SPSS for windows 24.0 program, it showsthat:

\section{A. Classic assumption test}

\section{Normality test}

A good regression model is to have normal or near normal data distribution (Ghozali, 2011: 74). To test for normality, we can analyze the distribution of data on the diagonal axis of the Normal Probability Plot. The basis for decision making is Ringle, \& Sarstedt, 2014). that if the data is spread around the diagonal line, the regression model fulfills the normality assumption. Based on the results of the normality test with the Kolmogorov Smirnov Test, if the probability value is $>0.05$, the regression model fulfills the normality assumption. 
Volume 1 Issue 2 (2022)

THE EFFECT OF LEADERSHIP, ORGANIZATIONAL CULTURE AND COMPETENCY ON EMPLOYEE PERFORMANCE WITH WORKING DISCIPLINES AS INTERVENING VARIABLES IN THE KSOP OFFICE FOR SPECIAL BATAM

DOI: https://doi.org/10.54443/ijset.v1i2.8

Table 1.1 Normality One-Sample Kolmogorov-Smirnov Test The Influence of Leadership, Organizational Culture and CompetenceAgainst Work Discipline (Model 1)

\begin{tabular}{|ll|r|}
\hline & & $\begin{array}{c}\text { Unstandardized } \\
\text { Residual }\end{array}$ \\
\hline Normal Parameters ${ }^{\mathrm{a}}$ & Mean & 36 \\
& Std. Deviation & .0000000 \\
Most Extreme Differences & Absolute & 1.95253500 \\
& Positive & .121 \\
& Negative & .095 \\
Kolmogorov-Smirnov Z & & -.121 \\
Asymp. Sig. (2-tailed) & & .725 \\
\hline a. Test distribution is Normal. & .669 \\
\hline
\end{tabular}

Source: Data processed by SPSS 24.02020

Table 1.2 One-Sample Kolmogorov-Smirnov Test Normality Test The Influence of Leadership, Organizational Culture, Competence and Work Discipline Against Employee Performance (Model 2)

\begin{tabular}{|c|c|c|}
\hline & & $\begin{array}{c}\text { Unstandardized } \\
\text { Residual }\end{array}$ \\
\hline \multicolumn{2}{|l|}{$N$} & 36 \\
\hline \multirow[t]{2}{*}{ Normal Parameters ${ }^{a}$} & Mean & .0000000 \\
\hline & Std. Deviation & $2.8065597 \varepsilon$ \\
\hline \multirow[t]{3}{*}{ Most Extreme Differences } & Absolute & $.07 \varepsilon$ \\
\hline & Positive & .047 \\
\hline & Negative & $-.07 \varepsilon$ \\
\hline \multicolumn{2}{|l|}{ Kolmogorov-Smirnov Z } & $.46 s$ \\
\hline \multicolumn{2}{|l|}{ Asymp. Sig. (2-tailed) } & .981 \\
\hline s Nol & & \\
\hline
\end{tabular}

Source: Data processed by SPSS 24.0 2020

From Table 1.1 and Table 1.2 above, it is known that the probability test value (Model 1) is 0.669 and the probability test (Model 2) is $0.981>0.05$, so the researchdata for model 1 and model 2 are said to be normal. In addition to a probability test, the normality test can also be seen from the Histogram and Scatter plot below. 


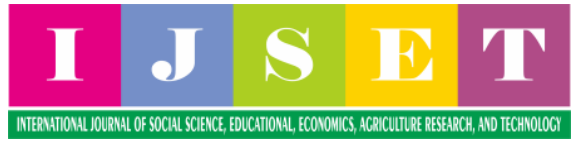

Histogram

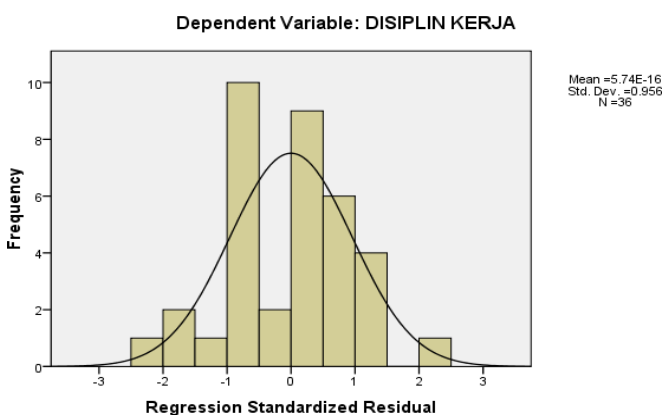

Figure 1.2 Normality Test (Histogram)

The Influence of Leadership, Organizational Culture and CompetenceAgainst Work

Discipline (Model 1)

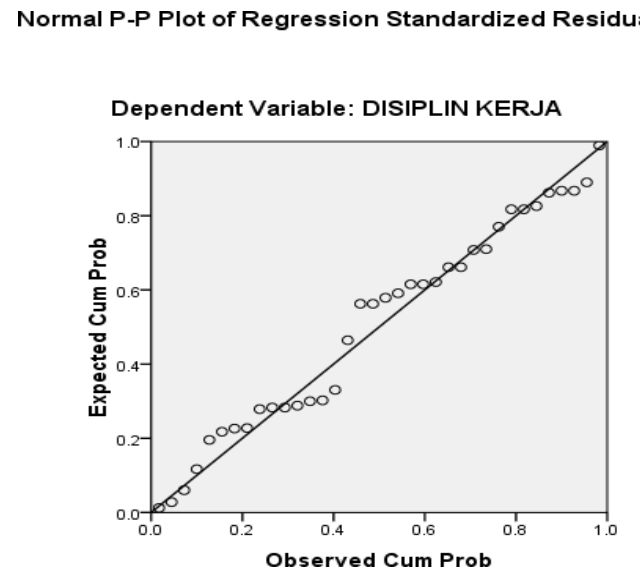

Source: Data processed by SPSS 24.02020

Figure 1.3 Normality Test (P-Plot)

\section{The Influence of Leadership, Organizational Culture and CompetenceAgainst Work Discipline (Model 1)}

Graph Histogram and PP Plot (Model 1) can be seen that the data spreads around the diagram and follows the regression model so that it can be concluded that the data processed is data that is normally distributed so that the normality test is fulfilled.

Below is a diagram of the normality test of the Influence of Leadership, Organizational

Histogram

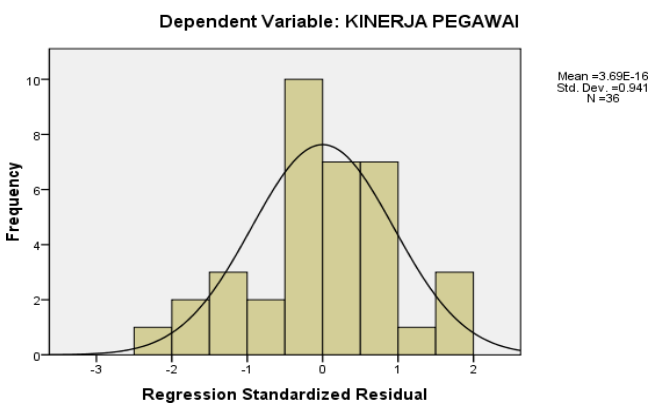

Culture, Competence and Work Discipline on Employee Performance (Model 2) 
THE EFFECT OF LEADERSHIP, ORGANIZATIONAL CULTURE AND COMPETENCY ON EMPLOYEE PERFORMANCE WITH WORKING DISCIPLINES AS INTERVENING VARIABLES IN THE KSOP OFFICE FOR SPECIAL BATAM

DOI: https://doi.org/10.54443/ijset.v1i2.8

Figure 1.4 Normality Test (Histogram)

The Influence of Leadership, Organizational Culture, Competence and WorkDiscipline on Employee Performance (Model 2)

Normal P-P Plot of Regression Standardized Residual

Dependent Variable: KINERJA PEGAWAI

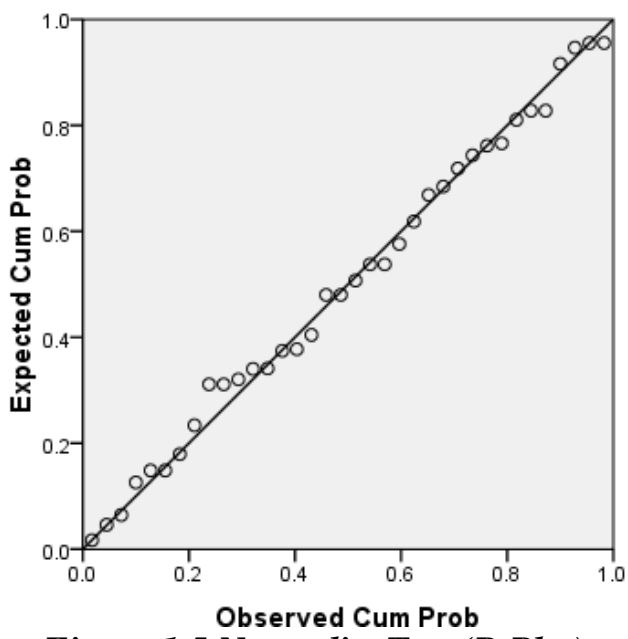

Figure 1.5 Normality Test (P-Plot)

The Influence of Leadership, Organizational Culture, Competence and WorkDiscipline on Employee Performance (Model 2)

Graph Histogram and PP Plot (Model 2) can be seen that the data spreads around the diagram and follows the regression model so that it can be concluded that the data processed is data that is normally distributed so that the normality test is fulfilled.

Findings

1. Leadership has a significant positive effect on work discipline

2. Organizational Culture has a positive and insignificant effect on Work Discipline

3. Competence has a significant positive effect on Work Discipline

4. Leadership has a positive and significant effect on employee performance

5. Organizational Culture has a positive and insignificant effect on Employee Performance

6. Competence has a negative and insignificant effect on employee performance

7. Work Discipline has a positive and insignificant effect on employee performance

\section{CONCLUSION}

This research was only conducted at KSOP Special Batam with a relatively small population and sample of only 36 respondents. This study cannot describe the overall performance conditions of employees in the Batam Special KSOP. So that further research is needed in a more outward and comprehensive manner. 


\section{REFERENCES}

Bismark, et.al, 2012, The Effect of Competence and Job Design on the Performance of Civil Servants at the Office of the Regent of South Solok, Journal of Administration and Public Policy, Vol.1 No.2.

Brigham, Eugene. F and Joel. F. Houston. 2010. Basics of Financial Management. Jakarta: Four Salemba.

Ilham, R. (2019). N et al. (2019). Comparative of the Supply Chain and Block Chains to Increase the Country Revenues via Virtual Tax Transactions and Replacing Future of Money. International Journal of Suplly Chain Management, 8(5).

Ilham, R.N., Erlina, K.A.F., Silalahi, A.S., Saputra, J. and Albra, W., 2019. Investigation of the bitcoin effects on the country revenues via virtual tax transactions for purchasing management. Int. J Sup. Chain. Mgt Vol, 8(6), p.737.

Makawi.Umar., Nomajatun and Abdul. 2015. "Analysis of the Effect of Competence on Employee Performance of the Banjarmasin City Industry and Trade Service". ISSN: 2476 - 9576 Volume 1 Number 1, October 2015. AL - ULUM Social Sciences and Humanities

Noe, Raymond A. 2002. Employee Training and Development. Second Edition. McGraw- Hill Irwin.

Raisa, Velinda. 2009 The Influence of Organizational Culture on Employee Performance of PT. Dain Global Indonesia.

Riinawati, R. (2021). Education Financial Management during Covid-19 Pandemic of Islamic Universities in South Kalimantan. Dinamika Ilmu: Jurnal Pendidikan, 383-396.

Robbins, Stephen P. 1996. Organizational Behavior. Jakarta: PT. Prenhalindo. Rumengan Jemmy, 2013. Research Methodology. Bandung: Citapustaka Media Perintis Sugiyono. 2003. Administrative Research Methods. Alfabeta Bandung

. 2011. Qualitative and Quantitative Research Methods R \& D. Bandung: CV. Alfabeta

. 2014. Qualitative and Quantitative Research Methods R \& D. Bandung: CV. Alfabeta Alfabeta

Sutrisno, Edi 2009. Human Resource Management, First Edition, First Edition, Jakarta: Kencana Prenada Media Group.

Sutrisno, Edi. 2011. Human Resource Management, Third Edition, Jakarta: Kencana Prenada Media Group.

http://bi.go.id/

http: /google.scholar.co.id/ 
Volume 1 Issue 2 (2022)

THE EFFECT OF LEADERSHIP, ORGANIZATIONAL CULTURE AND COMPETENCY ON EMPLOYEE PERFORMANCE WITH WORKING DISCIPLINES AS INTERVENING

VARIABLES IN THE KSOP OFFICE FOR SPECIAL BATAM

DOI: https://doi.org/10.54443/ijset.v1i2.8 